\title{
Reducing sap-sucking pests infesting Eggplant using biological control agent and colored plastic soil mulches under green house
}

\author{
Inas M. Y. Mostafa', Mona I. Ammar'1, Hayam M. Saad ${ }^{1}$ and S.M. Abolmaaty ${ }^{2}$ \\ ${ }^{1}$ Plant Protection Research Institute, Agricultural Research Center (ARC), Dokki, Giza, Egypt. \\ ${ }^{2}$ The Central Laboratory for Agriculture Climate, Agricultural Research Center (ARC), Dokki, Giza, \\ Egypt.
}

Received: 10 Nov. 2019 / Accepted 09 Jan. 2020 / Publication date: 25 Jan. 2020

\begin{abstract}
Field trial was conducted during two successive seasons on 2017- 2018 and 2018 - 2019 at greenhouse experimental area, Dokki, Giza Governorate. This study aims to evaluating the efficiency of different colored mulches and biological control Chrysoperla carnea) (Stephens), agents well as the effect of some environmental factors on the reduction of population density of the main sapsucking pests infesting eggplant (Solanum melanogena L.) and yield. The trials were used two treatments; White cover $+C$. carnea agent, Black cover $+C$. carnea agent, only colored mulches and without colored mulches or biological agent The results revealed that there are significant differences between using colored mulches with $\mathrm{BC}$ on population densities of some pests the whitefly, Bemisia tabaci (Genn.) and the spider mite, Tetranychus urticae (Koch). Data showed that the relationship between different treatments of management on population density of B. tabaci and $T$. urticae with decrease of crop yield for eggplant were highly significant effect of different treatments. These results revealed significant negative effects of maximum temperature and minimum temperature on the seasonal fluctuations of B. tabaci and T. urticae throughout in both season. While in the mean percentages of relative humidity found insignificant positive effects.

Recommendation: the paper recommendation by cover soil surface with black or white mulch and use $\mathrm{BC}$ to reduce population of whitefly and red mite and increase yield.
\end{abstract}

Keywords: eggplant, Solanum melanogena L., BCG, Chrysoperla carnea covering soil, ecosystems, population densities, Bemisia tabaci, Tetranychus urticae, Maximum temperature, Minimum temperature, relative humidity, soil temperature and yield.

\section{Introduction}

Integrated pest management (IPM) is a systemic approach in which interacting components (mainly control measures) act together to maximize the advantages (mainly producing a profitable crop yield) and minimize the disadvantages (mainly causing risk to human and environment) of pest control programs (Fathipour and Sedaratian 2013). IPM has also been defined as a pest population management system that uses all suitable techniques in a compatible manner to reduce pest populations and maintain them at levels below those causing economic injury (Kogan 1998). A fundamental component of an IPM program for any crop is an understanding of the compatibility of control tactics that we will integrate to control a target pest. Eggplant, Solanum melongena L. (Solanaceae), is grown in both fields and greenhouses worldwide and is one of the main vegetables in Egypt (Khanamani et al. 2012). This crop is attacked by various pests including Whitefly، Bemisia tabaci (Genn.), and spider mites, Tetranychus urticae Koch the most important pest of eggplant (Yadav \& Kumawat, 2013 and Mona \& Rahouma 2018). Bemisia tabaci (Genn.), make direct and indirect damage (Berlinger, 1986). Direct damage startups by sucking plant sap from the plant foliage, while Indirect damage due to the accumulation of honeydew that is considered as a good media for sooty mold growth, vectoring of plant viruses, so a few population of these pest is sufficient to cause considerable damage to the importance crop (Francki, 1979; Cohen and Berlinger, 1986; Berlinger, 1986 ; Conte, 1998; Devasahyam, 1998; Stansly et al., 2004; Baiomy, 2008; Hanafy et al. 2014 and Mona \& Rahouma 2018). Two- spotted spider mite, Tetranychus urticae Koch attacking a wide spectrum of economic plants, causing greet losses in their yield (Azouz, et al., 2014 and Mona \& Rahouma 2018). Different types of mulch effect on the vegetative growth and yield of plants through 
effect on soil temperatures which cause positive effect on the growth and yield of plants. The influence of polyethylene mulch type on soil temperature and crop response was dependent upon film color (Lippert \& Witing, 1964 and Wein \& Minotti 1988, Amna et al., 2012 and Mona \& Abolmaaty 2016), reported that plastic mulching increased total yield and shoot, compared with un-mulched plants. Concentrations of $\mathrm{N}, \mathrm{P}, \mathrm{K}, \mathrm{Ca}, \mathrm{Mg}, \mathrm{Cu}$ and $\mathrm{B}$ an increase the soil temperature may interfere in the nutrient levels in plants. As the temperature rises, calcium and phosphorus tend to diminish while nitrogen and potassium tend to increase, as well as the growth or the aerial part of the plant (Teasdale and Abdul-bakla, 1995). In vegetable agro-ecosystems, there are several native parasitoids and predators that can be effective in the control of crop pests (Nicoli and Burgio, 1997). The multi-use of natural enemies has showed an increase in their efficacies for controlling specific pests and for reducing the risk of virus infection (Perdikis et al., 2008). To produce healthy vegetables and fruits must be free from insecticide to avoid human being health problems and also produce a save product. The present work was carried out as an attempt to suggest certain integrated pest management (IPM)' tools to control insect' pests on eggplant plant. The present study aims to evaluating the efficiency of two different colors of mulches, multi-use of natural enemies and some environmental factors on reduction of population density to the main sap-sucking pests infesting eggplant crop in greenhouse conditions in Egypt.

\section{Material and Methods}

\section{Green houses}

The experiments were carried out at the greenhouse experimental area in Dokki, Giza, Egypt, using two commercial plastic greenhouses $640 \mathrm{~m} 2(16 \mathrm{~m} \times 40 \mathrm{~m}$ each). Eggplant seedlings were transplanted at October 15, 2017 and October 15, 2018 in the greenhouse as winter plantation, by 1000 eggplant (Solanum melanogena L.) plants. Eggplant crop was weighted during harvesting period. In the first greenhouse covered 5 rows with black mulch cover and 5 rows covered with white mulch cover for preventing the growing of weeds and releasing biological control agents (BC Chrysoperla carnea (Stephens). In the second greenhouse 3 rows were covered with black mulch cover and 3 rows covered with white mulch cover as a control treatment also, 4 rows was left free from any application. Daily data of minimum, maximum temperatures and relative humidity (R.H $\%$ ) and soil temp were obtained from the Central Laboratory for Agriculture Climate (CLAC), Dokki, Giza, Egypt.

\section{Sampling technique:}

Population densities of the targeted pests; B. tabaci and T. urticae were estimated weekly throughout the plant growing season (14 weeks). After three weeks for cultivation, chosen 25 random leaves at each treatments, was counted at three levels of the plant (top, middle and lower), using one square inch lens. In BCG, timing, number and rate of releases of biocontrol agent /release were determined according to the weekly average numbers of pests / plant. Five releases were done. Data were statistically analyzed using two ways ANOVA. data were statistically analyzed by correlation analysis between weather parameters and pests population. Reduction percentage in yield was calculated according to Henderson and Tilton equation (1955).

The total numbers were registered and the mean were calculated number of different pests on eggplant to study the effect of Maximum temperature, Minimum temp. ,Mean relative humidity (R.H $\%$ ) and soil temp population dynamics of these pests, the correlation (r) and the partial regression (b) were calculated between each of the above mentioned factors (Xs) and the weekly mean numbers of these pests.

Analysis of variance (ANOVA) was performed on infesting pests and yield variables (SAS, 1999) and appropriate error terms for the F tests of interactions were calculated separately. Comparisons of means were performed using the Duncan's multiple range test $(=0.05)$.

\section{Results and Discussion}

Effect of different treatments: White cover with $C$. carnea, Black cover with $C$. carnea, colored mulches covers and without mulches covers on targeted pests; Bemisia tabaci (Genn.) and 
spider mite, Tetranychus urticae (Koch) infesting eggplant are presented in Tables (1 and 2) and Figs. (1 and 2) during two successive seasons 2017-2018 and 2018- 2019, respectively. Results of statistical analysis revealed that there are significant differences between using (colored mulches with C. carnea agent vs the population densities of whitefly, B. tabaci and T. urticae during the two tested seasons, whereas $\mathrm{F}$ value $=19.2 * * *$ and L.S.D. $=12.5$ individuals $/ 300$ leaves in first season and in the second season $\mathrm{F}$ value $=28.44 * * *$ and L.S.D. $=17.15$ individuals $/ 300$ leaves, Whitefly, Bemisia tabaci.

Data in Tables (1 and 2) revealed that White cover with C. carnea agent and Black cover with C. carnea agent, were the most superior treatment in low infestation with immature stages of whitefly (nymphs) during two successive seasons followed by mulches only without biological agent, the last one was the free treatment without covers or biological agent that recorded the highest mean number in both seasons. These treatments white and black colors mulch and use $C$. carnea showing highly mortality $72 \%, 68 \%$ and $77 \%, 70 \%$ and Followed by third treatment using mulch only showing moderate effect $51 \%$ and $49 \%$, in two seasons, respectively. (Compared with control without any application found 1504 and 2100 individuals/300 leaves).

\section{Red mite, Tetranychus urticae}

Also, Tables (1 and 2) show that white and black colors mulch with using C. carnea agent were the most superior treatment in low infestation with immature stages of red mite during two successive seasons followed by mulch only and control without mulch which recorded the highest mean number in both seasons. These treatments the black and the white colors mulches covers and using C. carnea agent showing highly mortality $61 \%, 64 \%$ and $60 \%, 58 \%$ and followed by third treatment using mulch only showing moderate effect $49 \%$ and $45 \%$ in two seasons, respectively. (Compared with control without any application found 2320 and 1970 individuals/300 leaves).

Table 1: Effect of different treatments on reduction of some pests infesting eggplant and total yield in greenhouse - during 2017-2018 season - Giza Governorate.

\begin{tabular}{lcccc}
\hline Mulch color & $\begin{array}{c}\text { Reduction \% } \\
\text { of White fly }\end{array}$ & $\begin{array}{c}\text { Reduction \% } \\
\text { of Red spider }\end{array}$ & Mean & $\begin{array}{c}\text { Total yield } \\
\text { ( Kg ) }\end{array}$ \\
\cline { 2 - 3 } Immature stage & & $66 \mathrm{a}$ & 4687 \\
\hline White cover + C. carnea agent & 72 & 61 & $66 \mathrm{a}$ & 4790 \\
Black cover + C. carnea agent & 68 & 64 & $50 \mathrm{~b}$ & 3982 \\
Control only color mulch & 51 & 49 & 1912 & 1842 \\
\hline Control without color mulch & 1504 & 2320 & & \\
\hline
\end{tabular}

$\mathrm{F}$ value between treatments $=19.2^{* * *}$ sig. at $0.0001 \quad$ L.S.D. $=12.5$ individuals $/ 300$ leaves.

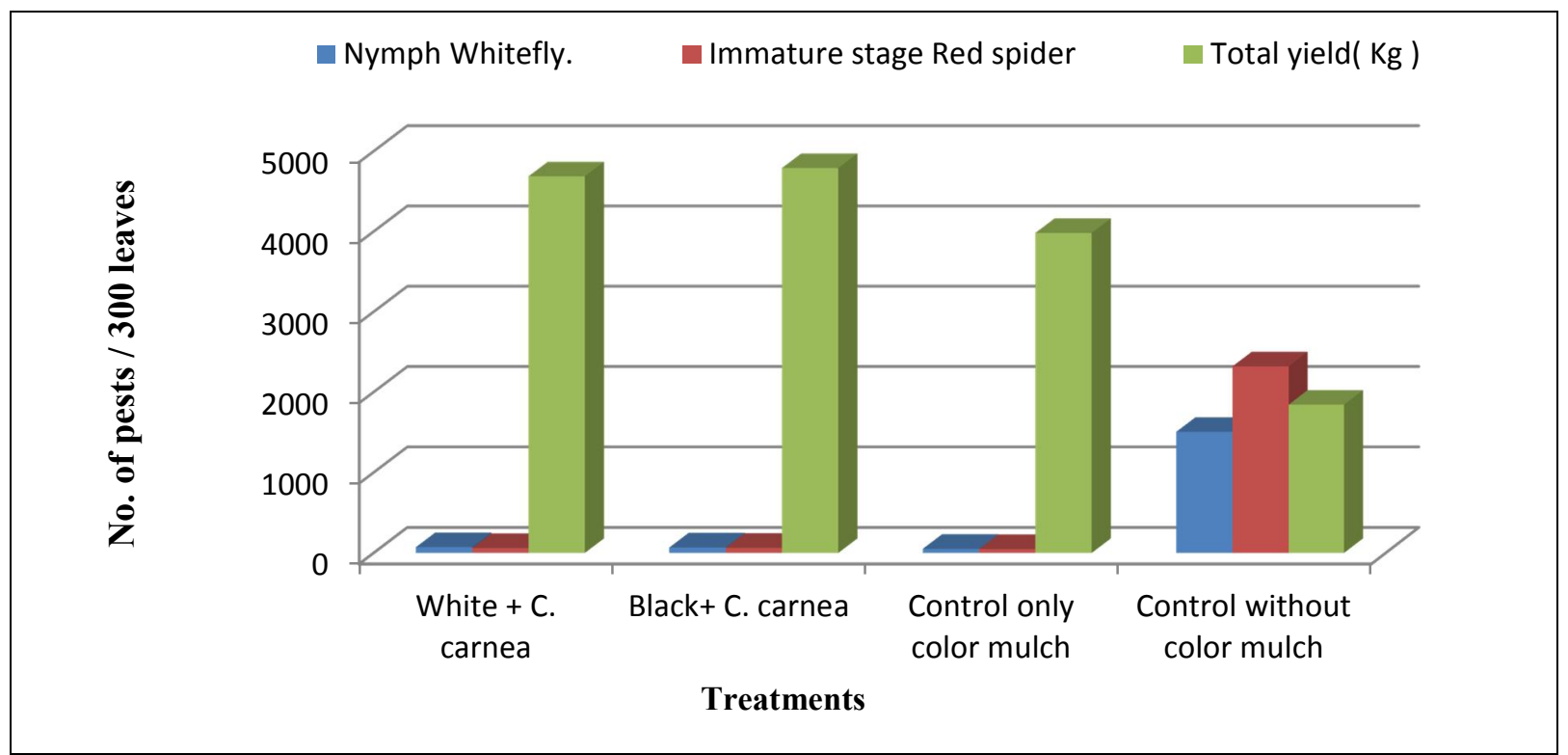

Fig. 1: Mean impact of treatments on weekly mean number of some pests infesting eggplant and weight yield during 2017 -2018 in greenhouse el - Giza Governorate. 
Table 2: Effect of different treatments on reduction of some pests infesting eggplant and total yield in greenhouse during 2018-2019 season - Giza Governorate.

\begin{tabular}{lcccc}
\hline Mulch color & $\begin{array}{c}\text { Reduction \% } \\
\text { of Whitefly }\end{array}$ & $\begin{array}{c}\text { Reduction \% Of Red } \\
\text { spider }\end{array}$ & Mean & $\begin{array}{c}\text { Total yield } \\
\text { ( Kg ) }\end{array}$ \\
\cline { 2 - 3 } Nymph. & 77 & Immature stage & & 68 a \\
\hline White cover+ C. carnea agent & 70 & 60 & 4888 \\
Black cover + C. carnea agent & 49 & 58 & 64 a & 4711 \\
Control only color mulch & 2100 & 45 & $47 \mathrm{~b}$ & 3512 \\
Control without color mulch & 1970 & 2035 & 1780 \\
\hline
\end{tabular}

$\mathrm{F}$ value between treatments $=28.44 * * *$ sig. at $0.0001 \quad$ L.S.D. $=17.15$ individuals $/ 300$ leaves.

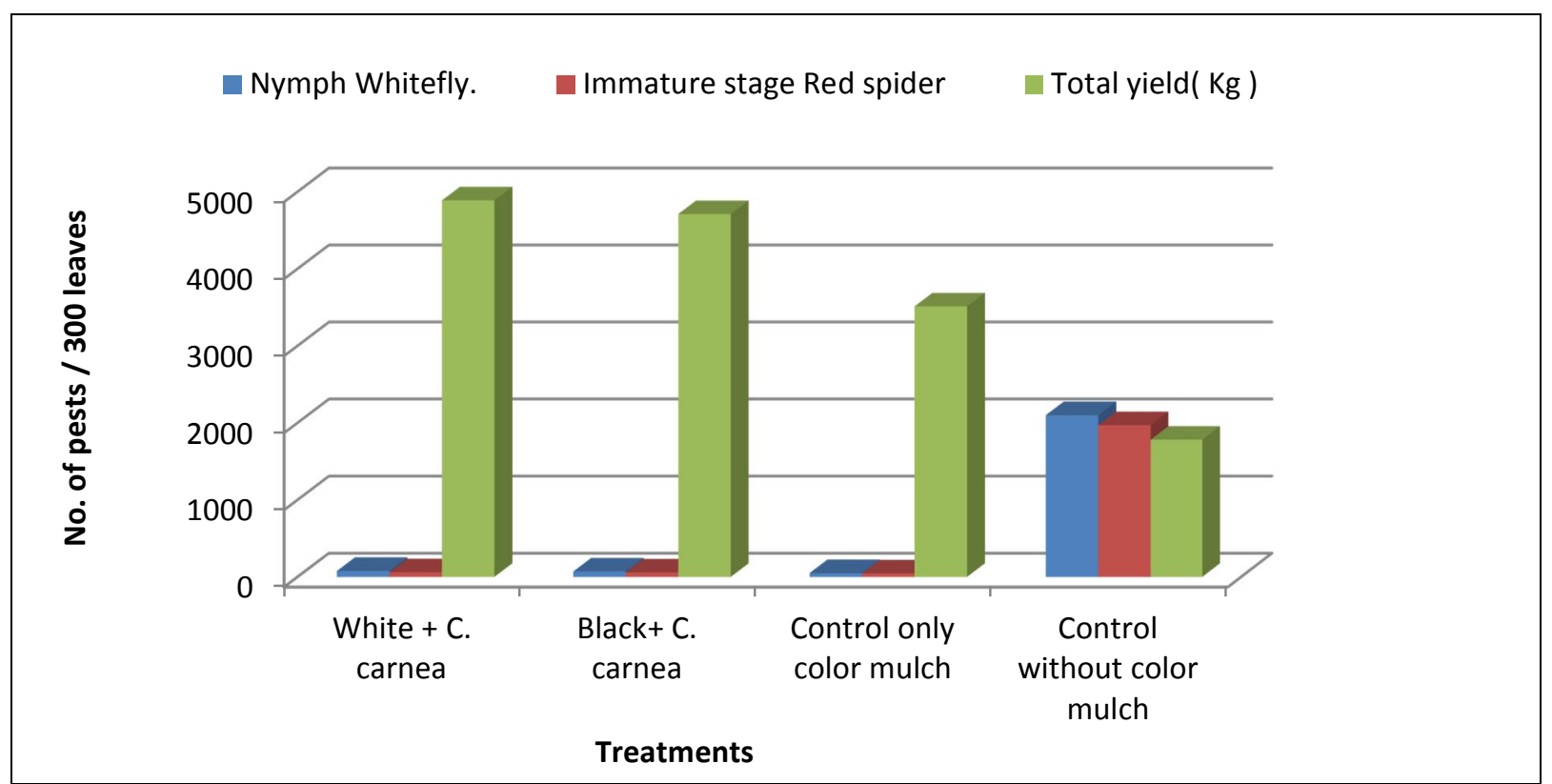

Fig. 2: Mean impact of treatments on weekly mean number of pests infesting eggplant and weight yield during 2018\&2019 at Giza Governorate.

\section{The treatments-yield relationship:}

The effect of different treatments of management of pests were recorded in both seasons 20172018 and 2018-2019 reflection on eggplant total yield was presented in Tables (1 and 2) and Figs. (1 and 2) for the two successive seasons. Referring the effect using different treatments of management was high significantly between pests population and weight yield.

Data in Table (3) showed that the relationship between different treatments of management on population density of $B$. tabaci and T. urticae with decrease of crop yield for eggplant were highly significant effect of different treatments (white colors mulch, use C. carnea, black colors mulch and use $C$. carnea, colors mulch use only and control without any applications in two seasons.

Table 3: Correlation and partial regression values of the yield and some pests and corresponding percentages of explained variance on eggplant plants at Giza Governorate during two seasons, 2017-2018 and 2018-2019 in greenhouse.

\begin{tabular}{|c|c|c|c|c|c|c|c|c|}
\hline Year & & 2017 & & & & 201 & 019 & \\
\hline Treatments & $\begin{array}{l}\text { White + } \\
\text { C. arnea }\end{array}$ & $\begin{array}{c}\begin{array}{c}\text { Black } \\
+ \\
\text { C. carnea }\end{array} \\
\end{array}$ & $\begin{array}{c}\text { only } \\
\text { color } \\
\text { mulch }\end{array}$ & $\begin{array}{c}\text { without } \\
\text { color } \\
\text { mulch } \\
\end{array}$ & $\begin{array}{l}\text { White + } \\
\text { C. arnea }\end{array}$ & $\begin{array}{c}\text { Black } \\
+ \\
\text { C. arnea }\end{array}$ & $\begin{array}{c}\text { only } \\
\text { color } \\
\text { mulch }\end{array}$ & $\begin{array}{c}\text { without } \\
\text { color } \\
\text { mulch } \\
\end{array}$ \\
\hline Correlation (r) & $-0.835^{*}$ & $-0.779 *$ & $-0.677^{*}$ & $\begin{array}{l}-0.354 \\
\text { insig. }\end{array}$ & $-0.828 *$ & $-0.811^{*}$ & $-0.512^{*}$ & $\begin{array}{l}-0.301 \\
\text { insig. }\end{array}$ \\
\hline $\begin{array}{l}\text { Partial regression } \\
\text { (b) }\end{array}$ & -0.033 & -0.043 & -1.09 & -3.14 & -0.030 & -0.032 & -2.87 & -7.00 \\
\hline F value & $3.53 *$ & $7.18^{*}$ & $\begin{array}{l}2.55 \\
\text { insig. }\end{array}$ & $\begin{array}{r}0.41 \\
\text { insig. }\end{array}$ & $5.22 *$ & $6.65^{*}$ & $\begin{array}{l}1.90 \\
\text { insig. }\end{array}$ & 0.33 insig. \\
\hline E.V & 87 & 80 & 56 & 10 & 88 & 82 & 50 & 8 \\
\hline
\end{tabular}

$\mathrm{r}=$ Correspondent correlations, $\mathrm{b}=$ Partial regression, $\mathrm{E} . \mathrm{V}=$ Explained Variance 
In the first season, whereas " $r$ " values were $-0.835,-0.779,-0.677$ and -0.354 , while " $b$ " values were $-0.03 \mathrm{Kg},-0.04 \mathrm{Kg},-1.09 \mathrm{~kg}$, and $-3.14 \mathrm{Kg}$ with mean of both seasons, respectively. These values of $(\mathrm{E} . \mathrm{V} \%)$ indicated that the different treatments were responsible percentage for $87 \%, 80 \%, 56 \%$ and $10 \%$ in the average weight. In the second season, whereas " $r$ " values were $-0.828,-0.811,-0.512$ and -0.301 , while "b" values were $-0.03 \mathrm{Kg},-0.03 \mathrm{Kg},-2.78 \mathrm{~kg}$, and $-7.00 \mathrm{Kg}$ with mean of both seasons, respectively. These values of $(\mathrm{E} . \mathrm{V} \%)$ indicated that the different treatments were responsible percentage for $88 \%, 82 \%, 50 \%$ and $8 \%$ in the average weight.

\section{The combined effect of some weather factors:}

In both greenhouses, weekly accumulated means of maximum, minimum temperatures and relative humidity ranged $\left(27.37-29.22^{\circ} \mathrm{C}\right)$ for maximum, $\left(15.29-16.44^{\circ} \mathrm{C}\right)$ for minimum temperatures showed significant negative effects $(\mathrm{r}=-0.863,0.004$ and $-0.715,0.016)$ in first season and in second season found $(\mathrm{r}=-0.714,0.01$ and $-0.611,0.05)$ with whitefly and red mite populations in different treatments(white colors mulch, use C. carnea, black colors mulch and use $C$. carnea, colors mulch use only and control without any applications), respectively. Correspondent correlations with the minimum temperature were $(\mathrm{r}=-0.765,0.02$ and $-0.701,0.04)$ in first season and in second season found $(\mathrm{r}=-0.717,0.04$, and $-0.848,-0.01)$ mean relative humidity $(52.6-60.7 \%)$ showed insignificant positive effects $(\mathrm{r}=0.513,0.07$ and $0.315,0.17)$ in first season and in second season found $(\mathrm{r}=$ $0.256,0.91$ and $0.211,0.85)$ with whitefly and red mite populations in different treatments.

These results were in line with those obtained by (Lippert \& Witing, 1964; Wein \& Minotti. 1987; Teasdale \& Abdul-bakla, 1995; Lamont 1993; Tagliavini et al . 1991; McMichael \& Burke 1998, Abdrabbo et al 2009 , Moses Mutetwa \& Tuarira Mtaita.2014, Mona \& Abolmaaty 2016 and Mona \& Rahouma 2018).

\section{Conclusion}

The colored mulches and biological control agent using to grown eggplant in winter season has a significant effect on the growth and yield. The mulch colors and (BC) have effect on pests population whereas decreased mean number of pests.

\section{References}

Amna, M. H. Maklad, S.M. Abolmaaty, M.K. Hassanein, and N. Y. Abd El-Ghafar, 2012. Impact of Type of Greenhouse Cover Sheets on Certain Major Cucumber Pests under Protected Cultivation. New York Science Journal. 5(7) http://www.sciencepub.net/newyork.

Azouz, H. A., E. M. A. Yassin, A. Mariam, El-Sanady and M. Aziza, Abou-Zaid, 2014. Field and laboratory studies on three eggplant cultivars to evaluate their relative susceptibility to some piercing sucking pests with relation of leaf constituents. J. Plant Prot. and Path., Mansoura Univ., Vol. 5 (11): $995-1005$.

Baiomy, Fatina, A.M., 2008. Efficiency of modern methods for controlling some vegetable pests in greenhouses in Egypt and Morocco. PhD. Thesis, Ins. African Res. Studies, Cairo Univ. 154pp.

Berlinger, M.J., 1986. Host plant Resistance to Bemisia tabaci . Agric. Ecosystems Env.., 17: 69-82.

Cohen, S. and M.J. Berlinger, 1986. Transmission and cultural control of whitefly-borne viruses. Agric.Ecosystems Env., 17: 89-97.

Conte, L., 1998. The technique of "banker plants" for biological control of Aphis gossypii on cucumber. Informatora Agrario., 54 (36): 71-75.

Devasahayam, S., K.M.A. Koya, and P.P. Reddy, 1998. IPM in spices - challenges for the future. Environmental implications and thrusts, Banalore, India, 157-164.

Fathipour, Y., and A. Sedaratian, 2013. Integrated management of Helicoverpa armigera in soybean cropping systems, pp. 231-280. In H. El-Shemy (ed.), Soybean-pest resistance. InTech, Rijeka, Croatia.

Francki, R.I.B., D.W. Mossop, and T. Hatta, 1979. Cucumber Mosaic Virus. CMI/AAB Descriptions of Plant Viruses No. 213.

Henderson, C.F. and E.W. Tilton, 1955. Tests with acaricides against the brown wheat mite. J. Econ. Entomol., 48: 157-161. 
Hanafy, A.R.I., Baiomy, Fatina and A.M. Tantawy, Maha, 2014. Comparison between the infestation rate of certain pests on cucumber and kidney bean and its relation with abiotic factors and anatomical characters. Egypt. Acad. J. Biolog. Sci., 7(2): 63 - 76.

Khanamani, M., Y. Fathipour, H. Hajiqanbar, and A. Sedaratian, 2012. Reproductive performance and life expectancy of Tetranychus urticae (Acari: Tetranychidae) on seven eggplant cultivars. J. Crop Prot., 1: 57-66.

Kogan, M. 1998. Integrated pest management: historical perspectives and contemporary developments. Annu. Rev. Entomol., 43: 243-270.

Lamont Jr., W.J., 1993. Plastic mulches for the production of vegetable crops. Hort Tecnology, 3:(1): 35-39.

Lippert, T.L.H. and F.L. Witing, 1964. Soil moisture under bands of petroleum and polyethylene mulches. Proc. Amer. Soc. Hort. Sci., 85: 541-546.

McMichael, B.L., and J.J. Burke, 1998. Soil temperature and root growth, Hort. Science, 33:947-951.

Mona I. Ammar and S.M. Abolmaaty, 2016. Effect of Different Colors Mulch on Population Density of Some Pests Infesting Cucumber Plants and on Cucumber Yield. Egypt. Acad. J. Biolog. Sci. (A. Entomology).9 (4):153- 162.

Mona I. Ammar and A. Rahouma, 2018. Management of Pests Infesting Eggplant Using some Insecticides and Oils and their Relationship with Crop Yield under Greenhouse. Journal of Plant Protection and Pathology, 9. 465-469.

Moses M., and T. Mtaita , 2014. Effect of different mulch colors on cucumberproduction. J. Glob. Innov. Agric. Soc. Sci., 2(4): 178-184.

Nicoli, G., and G. Burgio, 1997. Mediterranean biodiversity as source of new entomophagous species for biological control in protected crops. IOBC/WPRS Bull, 20: 27-38.

Perdikis, D.C., E. Kapaxidi and G. Papadoulis, 2008. Biological control of insect and mite pests in greenhouse solanaceous crops. Eur. J. Plant Sci. Biotechnol., 2: 125-144

SAS Institute, 1999. SAS User's guide: Statistics SAS Inst., Cary, N.C.

Stansly, P. A., P. A. Sanchez, J. M. Rodriguez, F. Canizares, A. Nieto, M. J. Lopez Leyva, M. Fajardo, V. Suarez and A. Urbaneja, 2004. Prospects for biologicalcontrol of Bemisia tabaci (Homoptera, Aleyrodidae) in greenhouse tomatoes of southern Spain. Crop Protection, 23:701712.

Teasdale, J.R. and A.A. Abdul-Bakl, 1995. Soil temperature and tomato growth associated with black polyethylene and hairy vetch mulches. J. Amer. Soc. Hort. Sci., 120(5): 848-853.

Wien, H.C., and P. L. Minotti, 1987. Growth, yield and nutrient uptake of transplanted fresh market tomatoes as affected by plastic mulch and initial nitrogen rate. J. Amer. Soc. Hort. Sci., 112:759-763.

Wien, H.C. and P. L. Minotti, 1988. Increasing Yield of Tomatoes with Plastic Mulch and Apex Removal. J. Amer. Soc. Hort. Sci., 113:342-347.

Yadav, S. R., and K. C. Kumawat, 2013. Assessment of crop losses due to insect pests of brinjal, Solanum melongena L. Insect Environment, 19: 16-18.

Younes, A. A., S. M. Soliman and S. E. Saadoon, 2001. Ecological studies on some sucking insects and mite associated with certain soygreen bean cultivars. J. Agric. Sci. Mansoura Univ., 26: 4551-4558. 